\title{
Solid-State NMR Structural Measurements on the Membrane-Associated Influenza Fusion Protein Ectodomain
}

\author{
Jaime Curtis-Fisk, ${ }^{\dagger}$ Casey Preston, ${ }^{\ddagger}$ Zhaoxiong Zheng, ${ }^{\dagger}$ R. Mark Worden,${ }^{\ddagger}$ and David P. Weliky ${ }^{*, \dagger}$ \\ Departments of Chemistry and Chemical Engineering, Michigan State University, East Lansing, Michigan 48824
}

Received May 21, 2007; E-mail: weliky@chemistry.msu.edu

Enveloped viruses such as HIV and influenza virus (IFV) are enclosed by a membrane which is obtained from an infected host cell. Infection of a new cell begins with joining or "fusion" of the viral and host cell membranes with an end result of a single membrane and the viral nucleocapsid in the host cell cytoplasm. Although membrane fusion is thermodynamically allowed, the rates of uncatalyzed membrane fusion are typically small. For this reason, enveloped viruses have fusion proteins in their membranes that bind to the host cell membranes and catalyze fusion. ${ }^{1}$ This paper describes studies of a large and functional domain of the IFV hemagglutinin (HA) fusion protein and includes bacterial expression and isotopic labeling of the protein, characterization of its folding and fusion activity, and membrane incorporation and solid-state nuclear magnetic resonance (SSNMR) structural measurements.

The HA protein is composed of HA1 and HA2 subunits. HA1 lies completely outside the virus, while HA2 has a $\sim 185$ residue $\mathrm{N}$-terminal ectodomain that lies outside the virus, a $\sim 25$ residue transmembrane domain, and a $\sim 10$ residue $\mathrm{C}$-terminal endodomain that is inside the virus. ${ }^{2}$ The IFV is taken into the host respiratory epithelial cell by receptor-mediated endocytosis, and the cell physiological processes lower the $\mathrm{pH}$ of the endosome to $\sim 5$. The HA1 and HA2 subunits dissociate, and a large HA2 structural change results in exposure of the $\sim 20$ residue $\mathrm{N}$-terminal "fusion peptide" (IFP) region. The IFP binds to endosomal membranes, and membrane fusion occurs. There has been a $\mathrm{pH} 7.5$ structure of the HA1/HA2 ectodomain complex crystallized from aqueous solution and a $\mathrm{pH} 4.4$ structure of residues $34-178$ of HA2 that forms the "soluble ectodomain" (SHA2) and which was also crystallized from aqueous solution. ${ }^{2,3}$ In addition, there have been liquid-state NMR structures of IFP in detergent micelles as well as electron spin resonance measurements of motion and membrane insertion of specific residues of IFP and of a HA2 construct composed of residues $1-127.4,5$ The present work is on a "FHA2" full ectodomain construct composed of residues 1-185 of HA2 and an eight residue C-terminal tag (Figure 1A). SSNMR has the potential for providing high-resolution structural information for FHA2 in the physiologically relevant membrane-bound state and for addressing structural effects of factors that reduce fusion activity including neutral $\mathrm{pH}$ and mutations.

There have been some previous applications of SSNMR to other large bacterial and human membrane proteins as well as membraneassociated IFP, and our study builds on this work. ${ }^{6-10}$ SSNMR requires efficient production of $>10 \mathrm{mg}$ quantities of isotopically labeled protein, and this was accomplished by FHA2 expression in Escherichia coli cells. Significant isotopic labeling requires expression in minimal media which lacks amino acids, but it was found that the purified FHA2 yield was $\sim 0.1 \mathrm{mg} / \mathrm{L}$ fermentation culture for $E$. coli grown only in minimal media. The successful approach was growth to OD 7 in a rich LB medium followed by a

$\dagger$ Department of Chemistry.
$\ddagger$ Department of Chemical Eng

¥Department of Chemical Engineering.
(A)

GLFGAIAGFIENG $\underline{W}$ EGMIDG $\underline{W}$ YG FRHQNSEGTGQA ADLKSTQ AAIDQINGKLNRVIEKTNEKF HQIEKEFSEVEGRIQDLEKYVE DTKIDLWSYNAELLVALENQ TIDLTDSEMNKLFEKTRRQLRE NAEEMGNGSFKIYHKCDNACI ESIRNGTYDHDVYRDEALNN

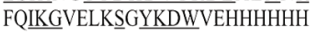

(C)

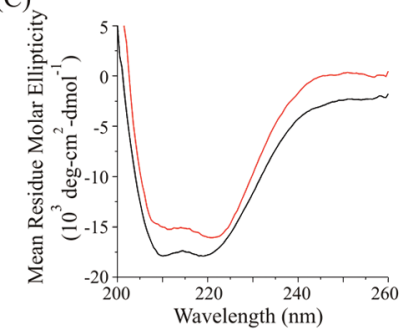

(B)

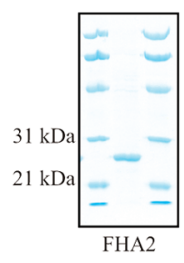

(D)

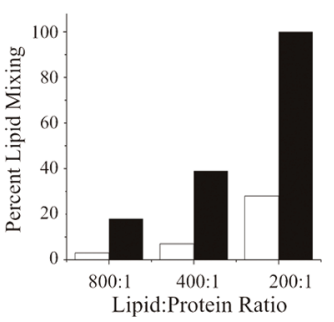

Figure 1. (A) FHA2 amino acid sequence from the influenza X31 strain. Each of the underlined residues is a first residue in a unique sequential pair. (B) SDS-PAGE gel of purified FHA2, MW = $22.5 \mathrm{kD}$. (C) Circular dichroism spectra at $4{ }^{\circ} \mathrm{C}$ of FHA2 in $0.5 \%$ BOG detergent at pH 5.0 (red line) and $\mathrm{pH} 7.4$ (black line). (D) Final extent of lipid mixing in vesicles of $\mathrm{LM}^{7}$ induced by FHA2 at pH 5.0 (filled bars) and pH 7.4 (open bars).

switch to minimal medium composed of glucose, salts, and the labeled amino acids. ${ }^{11}$ Although there has been progress in SSNMR assignment and structure determination of uniformly ${ }^{13} \mathrm{C},{ }^{15} \mathrm{~N}$-labeled membrane proteins, it was decided to begin with amino acid type labeling so that assignment would be more straightforward. ${ }^{12-14}$ FHA2 purification was done using $0.5 \% N$-laurylsarcosine detergent, and FHA2 with $>95 \%$ purity was obtained using a cobalt resin which bound the FHA2 histidine tag (Figure 1B). Yields of $\sim 8$ g cell mass and $\sim 3 \mathrm{mg}$ purified FHA2 per liter fermentation culture were obtained with this approach.

The FHA2 was exchanged into a solution of $0.5 \% \beta$-octylglucoside detergent (BOG) in $5 \mathrm{mM}$ HEPES/10 mM MES ("HM buffer") at $\mathrm{pH}$ 7.4. The overall secondary structure as a function of $\mathrm{pH}$ was probed with circular dichroism (CD) spectroscopy (Figure 1C). Observation of CD minima at 208 and $222 \mathrm{~nm}$ at both $\mathrm{pH} 5.0$ and $\mathrm{pH} 7.4$ was consistent with a significant fraction of helical conformation. The $\theta_{222 \mathrm{~nm}}$ value of $-16000 \mathrm{deg} \cdot \mathrm{cm}^{2} / \mathrm{dmol}$ at $\mathrm{pH} 5.0$ correlated with $\sim 50 \%$ of the residues in helical conformation and can be compared to the $\sim 60 \%$ of the residues in helical conformation expected if the SHA2 and IFP regions of detergent-associated FHA2 have the same conformations observed in their respective structures. A common assay to probe fusion peptide-induced membrane perturbation is peptide-induced lipid mixing (LM) between different unilamellar vesicles. By this assay, FHA2 was a potent fusogen and worked at $\sim 10$-fold lower concentrations than has been observed for IFP (Figure 1D). ${ }^{15,16} \mathrm{At}$ FHA2/lipid $\sim 0.001$, the LM rate was $>0.5 \mathrm{~s}^{-1}$ and is $>10$-fold larger than LM rates observed for fusion peptides at higher ratios. ${ }^{15}$ There was also a striking $\mathrm{pH}$ dependence of FHA2-induced lipid 

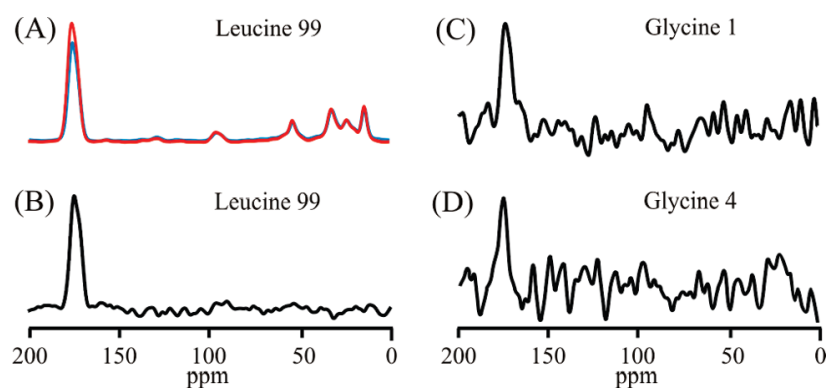

Figure 2. ${ }^{13} \mathrm{C}$ SSNMR spectra of membrane-associated FHA2. (A) REDOR $S_{0}$ (red) and $S_{1}$ (blue) spectra for a Leu- ${ }^{13} \mathrm{CO}$, Val- ${ }^{15} \mathrm{~N}$ sample and (B-D) $S_{0}-S_{1}$ spectra, respectively, representing ${ }^{13} \mathrm{CO}$ signals from the L99, G1, and G4 ${ }^{13} \mathrm{COs}$ and having peak chemical shifts of 178.0, 174.7, and 177.8 ppm, respectively. Signal averaging times were 1-3 days, and each spectrum was processed with $3 \mathrm{ppm}$ line broadening and baseline correction. Variation in signal-to-noise in B-D was due to differences in amounts of material, FHA2/lipid, and signal averaging times.

mixing which correlated with previous IFP studies and with the $\mathrm{pH}$ of IFV fusion. Enhanced $\mathrm{pH}$-dependent fusion has also been previously shown for other HA2 constructs. ${ }^{15,17}$ The CD and lipid mixing results are consistent with folded and active FHA2.

Reconstitution of FHA2 into membranes for SSNMR began with formation of a thin film of di- $O$-tetradecylphosphatidylcholine (DTPC, $32 \mathrm{mg}$ ), di- $O$-tetradecylphosphatidylglycerol (DTPG, $8 \mathrm{mg}$ ), and BOG $(160 \mathrm{mg})$. The film was dissolved in $5 \mathrm{~mL}$ of $\mathrm{pH} 5.0$ $\mathrm{HM}$ buffer, and this solution was mixed with a $2 \mathrm{~mL}$ solution containing FHA2 (5 mg) and pH 7.4 HM buffer with $0.5 \%$ BOG. BOG removal was achieved by dialysis at $4{ }^{\circ} \mathrm{C}$ into $\mathrm{pH} 5.0 \mathrm{HM}$ buffer with a membrane having $3 \mathrm{kD}$ cutoff and with one buffer change over 3 days. A hydrated membrane pellet was obtained by centrifugation by the slurry at $50000 \mathrm{~g}$ for $4 \mathrm{~h} .{ }^{18}$ In addition, etherrather than ester-linked lipids were used for these initial SSNMR studies to reduce the natural abundance carbonyl signal and simplify spectral interpretation.

In order to obtain residue-specific SSNMR spectra, ${ }^{13} \mathrm{CO}$ and ${ }^{15} \mathrm{~N}$ labelings were, respectively, chosen for the first and second residues of a unique sequential pair in FHA2. As displayed in Figure $2 \mathrm{~A}$, an unfiltered ${ }^{13} \mathrm{C}$ " $S_{0}$ " spectrum was obtained with the rotational-echo double-resonance (REDOR) sequence while signals from ${ }^{13} \mathrm{COs}$ directly bonded to ${ }^{15} \mathrm{Ns}$ were attenuated in the REDOR $S_{1}$ spectrum. ${ }^{19}$ Figure $2 \mathrm{~B}-\mathrm{D}$ displays $S_{0}-S_{1}$ difference spectra which were filtered ${ }^{13} \mathrm{CO}$ signals from different unique sequential pairs. ${ }^{13} \mathrm{CO}$ labeling of $>70 \%$ was suggested by comparison of ${ }^{13} \mathrm{CO} /$ natural abundance ${ }^{13} \mathrm{C} \alpha$ intensity ratios in $S_{0}$ spectra, and $>70 \%{ }^{15} \mathrm{~N}$ labeling was suggested by comparison of $S_{0}$ and $S_{1}{ }^{13} \mathrm{CO}$ intensities. There are well-known correlations between ${ }^{13} \mathrm{CO}$ chemical shifts and local conformation with distributions of $178.5 \pm 1.3$ and $175.7 \pm 1.5 \mathrm{ppm}$ for Leu in helical and $\beta$-strand conformations, respectively, and corresponding distributions of $175.5 \pm 1.2$ and $172.6 \pm 1.6 \mathrm{ppm}$ for Gly. ${ }^{20}$ The peak ${ }^{13} \mathrm{CO}$ chemical shifts for G1, G4, and L99 were 174.7, 177.8, and $178.0 \mathrm{ppm}$, respectively, and were consistent with helical conformation. These results correlated with the helical conformations observed for L99 in the SHA2 crystal structure and for functionally critical G1 and G4 in the IFP structure in detergent. ${ }^{21}$ This NMR filtering approach had previously been applied to chemically synthesized fusion peptides, and the present work demonstrates general applicability to a large expressed membrane protein. ${ }^{7}$ Over $50 \%$ of the backbone FHA2 COs are in unique sequential pairs, so this particular SSNMR approach should be applicable to mapping the membrane-associated FHA2 conformation including regions which were not part of the previous SHA2 or IFP structures. Detection of residue-specific conformational changes as a function of $\mathrm{pH}$, membrane cholesterol, and mutations is also feasible and will provide data to assess existing structure-function models for HA2-mediated fusion.,21 For example, addition of membrane cholesterol has correlated with a helical to $\beta$-strand conformational change in the IFP and effects of cholesterol may now be examined in the full FHA2 protein. ${ }^{7,10}$ The SSNMR samples had $0.003<$ FHA2/lipid $<0.02$, and at larger FHA2,lipid, it may be possible to determine internuclear distances and other structural parameters with SSNMR methods. In addition, the FHA2 quantities are such that liquid-state NMR and diffraction methods could be applied to detergent-associated FHA2.

Acknowledgment. The FHA2 plasmid was provided by YeonKyun Shin, and NIH AI47153 provided financial support. Assistance and advice were provided by Chang Sup Kim, Jason Criscione, R. Michael Garavito, Jun Sun, and Honggao Yan.

Supporting Information Available: Detailed descriptions of cell growth, FHA2 expression, isotopic labeling, and purification, LM assay, $\mathrm{CD}$ and SSNMR spectroscopies, and membrane reconstitution at $\mathrm{pH}$ 7.4. This material is available free of charge via the Internet at http:// pubs.acs.org.

\section{References}

(1) Skehel, J. J.; Wiley, D. C. Annu. Rev. Biochem. 2000, 69, 531-569.

(2) Chen, J.; Skehel, J. J.; Wiley, D. C. Proc. Natl. Acad. Sci. U.S.A. 1999 96, 8967-8972.

(3) Wilson, I. A.; Skehel, J. J.; Wiley, D. C. Nature 1981, 289, 366-373.

(4) Han, X.; Bushweller, J. H.; Cafiso, D. S.; Tamm, L. K. Nat. Struct. Biol. 2001, 8, 715-720.

(5) Macosko, J. C.; Kim, C. H.; Shin, Y. K. J. Mol. Biol. 1997, 267, 11391148.

(6) Jaroniec, C. P.; Lansing, J. C.; Tounge, B. A.; Belenky, M.; Herzfeld, J.; Griffin, R. G. J. Am. Chem. Soc. 2001, 123, 12929-12930.

(7) Yang, J.; Parkanzky, P. D.; Bodner, M. L.; Duskin, C. G.; Weliky, D. P. J. Magn. Reson. 2002, 159, 101-110.

(8) Park, S. H.; Prytulla, S.; De Angelis, A. A.; Brown, J. M.; Kiefer, H.; Opella, S. J. J. Am. Chem. Soc. 2006, 128, 7402-7403.

(9) Wang, J.; Balazs, Y. S.; Thompson, L. K. Biochemistry 1997, 36, 16991703 .

(10) Wasniewski, C. M.; Parkanzky, P. D.; Bodner, M. L.; Weliky, D. P. Chem. Phys. Lipids 2004, 132, 89-100.

(11) Cai, M. L.; Huang, Y.; Sakaguchi, K.; Clore, G. M.; Gronenborn, A. M.; Craigie, R. J. Biomol. NMR 1998, 11, 97-102.

(12) Andronesi, O. C.; Becker, S.; Seidel, K.; Heise, H.; Young, H. S.; Baldus, M. J. Am. Chem. Soc. 2005, 127, 12965-12974.

(13) Buffy, J. J.; Traaseth, N. J.; Mascioni, A.; Gor'kov, P. L.; Chekmenev, E. Y.; Brey, W. W.; Veglia, G. Biochemistry 2006, 45, 10939-10946.

(14) Sharpe, S.; Yau, W. M.; Tycko, R. Biochemistry 2006, 45, 918-933.

(15) Epand, R. F.; Macosko, J. C.; Russell, C. J.; Shin, Y. K.; Epand, R. M. J. Mol. Biol. 1999, 286, 489-503.

(16) Haque, M. E.; McCoy, A. J.; Glenn, J.; Lee, J. K.; Lentz, B. R. Biochemistry 2001, 40, 14243-14251.

(17) Gray, C.; Tamm, L. K. Protein Sci. 1997, 6, 1993-2006.

(18) Petri, W. A.; Wagner, R. R. J. Biol. Chem. 1979, 254, 4313-4316.

(19) Gullion, T.; Schaefer, J. J. Magn. Reson. 1989, 81, 196-200.

(20) Zhang, H. Y.; Neal, S.; Wishart, D. S. J. Biomol. NMR 2003, 25, 173195.

(21) Li, Y. L.; Han, X.; Lai, A. L.; Bushweller, J. H.; Cafiso, D. S.; Tamm, L. K. J. Virol. 2005, 79, 12065-12076.

JA073644G 


\section{$\underline{\text { Supporting Information }}$}

Materials. The FHA2 sequence was ${ }^{1}$ GLFGAIAGFIENGWEGMIDGWYGFR HQNSEGTGQAADLKSTQAAIDQIN ${ }^{50}$ GKLNRVIEKTNEKFHQIEKEFSEVEGRIQD LEKYVEDTKIDLWSYNAELL ${ }^{100}$ VALENQHTIDLTDSEMNKLFEKTRRQLRENAEE MGNGSFKIYHKCDNACI ${ }^{150}$ ESIRNGTYDHDVYRDEALNNRFQIKGVELKSGYKD WVEHHHHHH and the FHA2 plasmid was obtained from Dr. Yeon-Kyun Shin at Iowa State University and contained the Lac promoter and kanamycin resistance. The plasmid was transformed into E. coli BL21(DE3) cells. Unless noted, all chemicals were purchased from Sigma-Aldrich (St. Louis, MO). LB medium was purchased from Acumedia (Lansing, MI) and $15 \mathrm{mg} / \mathrm{L}$ kanamycin was then added to it. M9 minimal medium contained per liter $6.8 \mathrm{~g} \mathrm{Na}_{2} \mathrm{HPO}_{4}, 3.0 \mathrm{~g} \mathrm{NaH}_{2} \mathrm{PO}_{4}, 0.50 \mathrm{~g} \mathrm{NaCl}, 1.0 \mathrm{~g} \mathrm{NH} 4 \mathrm{Cl}$, $0.25 \mathrm{~g} \mathrm{MgSO}_{4}, 10 \mathrm{~g}$ glucose and $15 \mathrm{mg}$ kanamycin. The initial $\mathrm{pH}$ of the M9 medium was adjusted to be 7.4. The feeding buffer contained $100 \mathrm{mM}$ sodium phosphate at $\mathrm{pH}$ 8.0 and $20 \mathrm{~g} / \mathrm{L}$ glucose. Buffer A contained $50 \mathrm{mM}$ sodium phosphate at $\mathrm{pH}$ 8.0, 300 $\mathrm{mM} \mathrm{NaCl}, 20 \mathrm{mM}$ imidizole, and $0.5 \%(\mathrm{w} / \mathrm{v}) \mathrm{N}$-laurylsarcosine detergent. Buffer B contained $50 \mathrm{mM}$ sodium phosphate at $\mathrm{pH} 8.0,300 \mathrm{mM} \mathrm{NaCl}, 250 \mathrm{mM}$ imidizole, and 0.5\% (w/v) N-laurylsarcosine detergent. Buffer C contained $5 \mathrm{mM}$ 4-(2-hydroxyethyl)-1piperazineethanesulfonic acid (HEPES) and $10 \mathrm{mM}$ 2-( $N$-morpholino)ethanesulfonic acid (MES) at pH 7.4 and 0.5\% $\beta$-octylglucoside (BOG) (Anatrace, Maumee, OH). Buffer D contained $5 \mathrm{mM}$ HEPES and $10 \mathrm{mM}$ MES at pH 5.0 and 0.5\% BOG. Buffer E contained $5 \mathrm{mM}$ HEPES at $\mathrm{pH}$ 7.0. Buffer F contained $5 \mathrm{mM}$ HEPES and $10 \mathrm{mM}$ MES at pH 7.4. Buffer $\mathbf{G}$ contained $5 \mathrm{mM}$ HEPES and $10 \mathrm{mM}$ MES at $\mathrm{pH}$ 5.0. 
Cell growth and protein expression. A $250 \mathrm{~mL}$ baffled Erlenmeyer flask containing 50 $\mathrm{mL}$ of LB medium was inoculated with a single colony of cells containing the FHA2 plasmid. The culture was grown for $\sim 12$ hours at $37^{\circ} \mathrm{C}$ in a shaker (New Brunswick, Edison, New Jersey) operating at $200 \mathrm{rpm}$. The $\mathrm{OD}_{600}$ of the culture reached a maximum value of $\sim 7$ and the cell suspension was subsequently diluted to $1 \mathrm{~L}$ in fresh LB medium in a $2.8 \mathrm{~L}$ baffled fernbach flask. After overnight growth at $37{ }^{\circ} \mathrm{C}$ with a shaking rate of $200 \mathrm{rpm}$, the $\mathrm{OD}_{600}$ of the $1 \mathrm{~L}$ culture reached a maximum value of $\sim 7$. The cell suspension was centrifuged at $9000 \mathrm{~g}$ at $4{ }^{\circ} \mathrm{C}$ and the resulting cell pellet mass was $>6 \mathrm{~g}$. It was found that using a baffled rather than a regular Erlenmeyer flask was important for achieving the large cell mass presumably because of better aeration with the baffled flask.

The cell pellet was resuspended in 1 L M9 medium and cell growth resumed while shaking at $37^{\circ} \mathrm{C}$ and $200 \mathrm{rpm}$. After 30 minutes and after 60 minutes of shaking, a $50 \mathrm{~mL}$ aliquot of feeding buffer was added that helped to maintain the $\mathrm{pH}$ and the glucose concentration in the medium and resulted in higher yield of FHA2. The $\mathrm{OD}_{600}$ of the cell suspension increased by $\sim 1.0$ during the 60 minutes of growth in M9 medium and the cells were in mid-log phase growth at this time. The shaker temperature was reduced to $23^{\circ} \mathrm{C}$ and $100 \mathrm{mg}$ of each isotopically labeled amino acid was added to the flask. After fifteen minutes, induction of FHA2 expression began with addition of IPTG to a final concentration of $0.2 \mathrm{mM}$. The induction period was 3 hours and ended with centrifugation of the cell suspension for 15 minutes at $9000 \mathrm{~g}$ and $4{ }^{\circ} \mathrm{C}$. The cell pellet mass was $>7 \mathrm{~g} / \mathrm{L}$ fermentation culture and the cell pellet was frozen at $-80{ }^{\circ} \mathrm{C}$ for $>12$ hours to enhance cell lysis. 
The above optimized protocol was based on variation of the following parameters: media composition, cell growth temperature, shaking rate, and oxygen and glucose concentrations, cell concentration at the start of induction, IPTG concentration, and temperature and duration of induction period. The isotopic labeling protocol was based on methods previous published by other groups (Marley, J.; Lu, M.; Bracken, C. J. Biomol. NMR 2001, 20, 71-75 and Cai, M.; Huang, Y.; Sakaguchi, K.; Clore, G. M.; Groneborn, A. M.; Craigie, R. J. Biomol. NMR 1998, 11, 97-102).

Purification. All buffers were refrigerated prior to use in the purification. The following protocol was optimized to obtain optimal purity and yield from $5 \mathrm{~g}$ cells. Purification of larger cell quantities may require further optimization. Cells $(5 \mathrm{~g})$ were suspended in 25 $\mathrm{mL}$ of buffer A and cell walls were lysed during 4 sonication periods of 1 minute duration with a 1 minute delay between sonication periods. Each period contained $0.8 \mathrm{~s}$ on/0.2 s off cycles with $80 \%$ amplitude during the on cycle. Cell debris was removed by centrifugation at $48000 \mathrm{~g}$ and $4{ }^{\circ} \mathrm{C}$ for 20 minutes and $0.5 \mathrm{~mL}$ of cobalt His-Select resin (Sigma) was added to the centrifugation supernatant. The FHA2 protein was bound to the resin during agitation for 1 hour at ambient temperature. Cobalt rather than nickel resin was used because there was strong binding of the SlyD protein to the nickel resin (Zhang, J. W.; Butland, G.; Greenblatt, J. F.; Emili, A.; Zamble, D. B. J. Biol. Chem. 2005, 280, 4360-4366). A resin pellet was formed by centrifugation at $1000 \mathrm{~g}$ for 1 minute and the pellet was transferred to a $10 \mathrm{~mL}$ disposable column (Biorad, Hercules, CA) and then washed with 3 column volumes $(1.5 \mathrm{~mL})$ of buffer A. FHA2 was eluted from the resin with 5 column volumes $(2.5 \mathrm{~mL})$ of buffer B and the FHA2 solution volume was subsequently reduced to $\sim 0.5 \mathrm{~mL}$ by centrifugation in a Vivaspin concentrator (Sartorius, 
Goettingen, Germany) whose membrane had a molecular weight cutoff of 3500 D. Buffer exchange was achieved by dilution of the FHA2 solution in the concentrator with buffer C followed by reconcentration. The dilution/concentration steps were repeated until the nominal buffer $\mathrm{C} /$ buffer B ratio $(\mathrm{v} / \mathrm{v})$ was $>1000$. The final FHA2 solution contained $\sim 2$ mg FHA2 in $\sim 2 \mathrm{~mL}$ buffer C; i.e. [FHA2] $\sim 50 \mu \mathrm{M}$. The FHA2 purity was $>95 \%$ as observed in a SDS page gel. Some fraction of the protein may have an N-terminal methionine (Chang Sup Kim, personal communication).

Preparation of large unilamellar vesicles (LUVS). Lipids and cholesterol were purchased from Avanti Polar Lipids (Alabaster, AL). The "LM3" mixture represented the approximate composition of host cells of the influenza virus (Worman, H.J.; Brasitus, T.A.; Dudeja, P.K.; Fozzard, H.A.; Field, M. Biochemistry 1986, 25, 1549-1555) and contained 1-palmitoyl-2-oleoyl-sn-glycero-3-phosphocholine (POPC), 1-palmitoyl-2oleoyl-sn-glycero-3 phosphoethanolamine (POPE), 1-palmitoyl-2-oleoyl-sn-glycero-3[phospho-L-serine] (POPS), sphingomyelin, phosphatidylinositol (PI) and cholesterol in a 10:5:2:2:1:10 mol ratio. One set of LUVs was made from LM3 (5.4 $\mu$ mol total lipid + 2.7 $\mu$ mol cholesterol $)$ mixture while another set was made from LM3 mixture $(0.6 \mu$ mol total lipid $+0.3 \mu \mathrm{mol}$ cholesterol) and an additional $2 \mathrm{~mol} \%$ of the lipid $N$-(7-nitro-2,1,3benzoxadiazol-4-yl)-phosphatidylethanolamine (N-NBD-PE) and 2 mol\% of the lipid $\mathrm{N}$ (lissamine Rhodamine B sulfonyl) phosphatidylethanolamine ( $N$-Rh-PE). Lipids and cholesterol were dissolved in chloroform and the chloroform was subsequently removed with nitrogen gas and overnight vacuum pumping. A $1 \mathrm{ml}$ aliquot of buffer $\mathrm{E}$ was added to each of the dry lipid/cholesterol mixture and the dispersion was homogenized with ten freeze-thaw cycles. LUVs were prepared by extrusion through a polycarbonate filter with 
100 nm diameter pores (Hope, M. J.; Bally, M. B.; Webb, G.; Cullis, P. R. Biochim. Biophys. Acta. 1985, 812, 55-65).

Lipid mixing assay. One feature of vesicle fusion is mixing of lipids between different vesicles. The NBD and Rh groups are fluorescent and quenching functionalities, respectively, so that lipid mixing between the fluorescently labeled and unlabeled LUVs will increase the average distance between fluorescent and quenching lipids and will be detected as increased fluorescence (Struck, D. K.; Hoekstra, D.; Pagano, R. E. Biochemistry 1981, 20, 4093-4099). Fluorescence was monitored in mixtures made from $\sim 1.9 \mathrm{~mL}$ of either buffer $\mathrm{F}$ ( $\mathrm{pH} 7.4$ ) or buffer $\mathrm{G}$ (buffer 5.0 ), $50 \mu \mathrm{L}$ of unlabeled LUV solution and $50 \mu \mathrm{L}$ of labeled LUV solution. The resultant solutions had [total lipid] = $150 \mu \mathrm{M}$, [total cholesterol] $=75 \mu \mathrm{M}$, and [labeled LUV] $/[$ unlabeled LUV] $=0.11$. The fluorimeter (Fluoromax 2, HORIBA Jobin Yvon Inc, Edison, NJ) was set with excitation and emission wavelengths of 465 and $530 \mathrm{~nm}$, respectively. For each data set, the " $F_{0}$ " fluorescence of the vesicle solution was recorded and then the " $F_{1}$ " fluorescence was detected after addition of an aliquot of FHA2 solution in buffer C. The typical FHA2 stock concentration was $\sim 100 \mu \mathrm{M}$ and the volume of buffer was adjusted in each trial so that the total solution volume $V_{F H A 2}+V_{\text {vesicles }}+V_{\text {buffer }}=2.0 \mathrm{~mL} . F_{1}$ was the equilibrium fluorescence of the FHA2/LUV solution as the time for the FHA2-induced fluorescence change was shorter than the $\sim 2 \mathrm{~s}$ dead time between addition of the FHA2 aliquot and sealing the fluorimeter enclosure. After measurement of $F_{1}$, a $10 \mu \mathrm{L}$ aliquot of a $20 \% \mathrm{w} / \mathrm{v}$ triton solution was added to the FHA2/LUV solution. The triton solubilized the vesicles and resulted in a large average distance between the fluorescent and quenching lipids and a maximum " $F_{2}$ " fluorescence. The "percent lipid mixing" was calculated using the 
literature convention (Yang, J.; Gabrys, C. M.; Weliky, D. P. Biochemistry 2001, 40, 8126-8137):

Percent lipid mixing $=100 \times\left(F_{1}-F_{0}\right) /\left(F_{2}-F_{0}\right)$

The typical variation in percent lipid mixing was $\pm 2 \%$ as determined by comparison of different trials with the same vesicle and FHA2 stocks and concentrations. As a control, fluorescence was also recorded with addition of aliquots of buffer $\mathrm{C}$ which did not contain FHA2. There was very little change in fluorescence and $F_{1}-F_{0}$ can therefore be attributed to FHA2- rather than BOG-induced lipid mixing.

Circular dichroism (CD) spectroscopy. Solutions were prepared with either buffer $\mathrm{C}$ or buffer D and with [FHA2] $=0.2 \mathrm{mg} / \mathrm{mL} \sim 10 \mu \mathrm{M}$. Spectra were obtained at $4{ }^{\circ} \mathrm{C}$ using a CD instrument (Chirascan, Applied Photophysics, Surrey, United Kingdom), a cuvette with $1 \mathrm{~mm}$ pathlength, a 260-200 nm spectral window, wavelength points separated by $0.5 \mathrm{~nm}$, and 0.5 seconds signal averaging per point. Each of the spectra in Fig. 1C in the main text is the difference between the spectrum of the FHA2 sample and a background spectrum of either buffer $\mathrm{C}$ or buffer D. A mean residue molar ellipticity $\theta_{222 \mathrm{~nm}}$ value of -33000 deg-cm ${ }^{2}-\mathrm{dmol}^{-1}$ corresponds to $100 \%$ helicity (O'Shea, E. K.; Rutkowski, R.; Kim, P. S. Science 1989, 243, 538-542).

Solid-state nuclear magnetic resonance (SSNMR) spectroscopy. Data were obtained with a 9.4 T instrument (Varian Infinity Plus, Palo Alto, CA), a triple resonance magic angle spinning (MAS) probe, and a $4.0 \mathrm{~mm}$ diameter rotor with $\sim 40 \mu \mathrm{L}$ sample volume. Typical parameters of the rotational-echo double-resonance (REDOR) pulse sequence were: (1) $8.0 \mathrm{kHz}$ MAS frequency; (2) a $6 \mu{ }^{1} \mathrm{H} \pi / 2$ pulse; (3) a $1.6 \mathrm{~ms}$ crosspolarization period with $63 \mathrm{kHz}{ }^{1} \mathrm{H}$ Rabi frequency and $80 \mathrm{kHz}{ }^{13} \mathrm{C}$ Rabi frequency; (4) a 
2 ms dephasing period with alternating $19 \mu \mathrm{s}{ }^{15} \mathrm{~N} \pi$ pulses and $8 \mu \mathrm{s}{ }^{13} \mathrm{C} \pi$ pulses and 88 kHz two-pulse phase modulation (TPPM) ${ }^{1} \mathrm{H}$ decoupling; (5) ${ }^{13} \mathrm{C}$ detection with $88 \mathrm{kHz}$ TPPM ${ }^{1} \mathrm{H}$ decoupling; and (6) $1 \mathrm{sec}$ delay. Data were acquired without $\left(S_{0}\right)$ and with $\left(S_{1}\right)$ the ${ }^{15} \mathrm{~N} \pi$ pulses during the dephasing period and respectively represented the full ${ }^{13} \mathrm{C}$ signal and the ${ }^{13} \mathrm{C}$ signal minus ${ }^{13} \mathrm{Cs}$ directly bonded to ${ }^{15} \mathrm{~N}$ nuclei. Because the FHA2 contained a ${ }^{13} \mathrm{CO} /{ }^{15} \mathrm{~N}$ unique sequential pair, the $S_{0}-S_{1}$ difference was predominantly the filtered signal of this pair (Yang, J.; Parkanzky, P. D.; Bodner, M. L.; Duskin, C. G.; and Weliky, D. P. J. Magn. Reson. 2002, 159, 101-110). Data were acquired at $-50{ }^{\circ} \mathrm{C}$ because of the three-fold higher signal to noise relative to $25{ }^{\circ} \mathrm{C}$ and because chemical shifts and presumably structure did not vary greatly as a function of temperature (Bodner, M. L.; Gabrys, C. M.; Parkanzky, P. D.; Yang, J.; Duskin, C. G.; Weliky, D. P. Magn. Reson. Chem. 2004, 42, 187-194). Spectra were externally referenced to the methylene carbon of adamantane at $40.5 \mathrm{ppm}$, which corresponds to the ${ }^{13} \mathrm{C}$ referencing used in liquid-state NMR of soluble proteins (Morcombe, C. R.; Zilm, K. W. J. Magn. Reson. 2003, 162, 479-486 and Zhang, H. Y.; Neal, S.; Wishart, D. S. J. Biomol. NMR, 2003, 25 , 173-195). Peak chemical shifts were determined with \pm 0.3 ppm precision. 